\title{
OPINI MASYARAKAT MENGENAI HATE SPEECH PADA MEDIA MASSA TERHADAP ULAMA (Studi Kasus pada Masyarakat Meulaboh, Aceh Barat)
}

\author{
Siti Nurkhafifah Marisa', Rena Juliana', Reni Juliani \\ I STAIN Teungku Dirungdeng Meulaboh \\ 2 Universitas Teuku Umar
}

\begin{abstract}
At present, there is much news of hate speech against ulama circulating in the mass media. Hate speech can have a negative impact on human relationships and between the religious communities developed to date. The purpose of this research is to discuss how the public opinion of Meulaboh presents to the mass media messages containing hate speech directed against ulama. This research used a qualitative approach by collecting data through interviews with 4 people from Meulaboh City and 2 lecturers of KPI STAIN Meulaboh. The results of this study show that having a huge impact on the news in the media for the community, especially the presence of gadgets, allows people to easily access a lot of the latest news. People who still hold strong religious values think the news is inappropriate. The news presented by the media is expected to be neutral and impartial, which can harm other parties.
\end{abstract}

\section{Keywords}

Opinion, Hate Speech, Mass Media, Ulama

\section{Correspondence Contact}

renajuliana@staindirundeng.ac.id

\section{PENDAHULUAN}

Menurut Nurcholish (2017:26) salah satu tantangan dalam persatuan adalah ujaran kebencian (hate speech) maraknya hate speech dapat berdampak buruk dalam hubungan sesama manusia dan antar umat beragama yang selama ini telah terbangun. Semua agama mengajarkan untuk saling berinteraksi, berdialog dengan saling mencintai, saling menyayangi dan saling melindungi.

Namun saat ini banyak kita temukan beredarnya pemberitaan di media masa yang berisi hate speech terhadap ulama. Di antara pemberitaan media terhadap kasus-kasus yang dikaitkan dengan ulama adalah sebagai berikut:

1. Habib Rizieq Resmi sebagai tersangka penodaan Pancasila pada Selasa, 31 januari 2017. Dalam berita tersebut Rizieq dinyatakan sebagai tersangka kasus dugaan penodaan Pancasila pada hari Senin (30/1/2017) yang melanggar pasal 154 a KUHP tentang Penodaan Lambang Negara dan Pasal 320 KUHP tentang Pencemaran terhadap orang yang sudah meninggal. Kasus ini berawal dari Sukmawati Soekarnoputri yang melaporkan HRS ke Bareskrim pada kamis 27/10/2016 karena mengatakan bahwa pancasila Sukarno ketuhanan ada di pantat sedangan pancasila Piagam Jakarta ketuhanan ada di kepala. Namun, pada Jumat 04 Mei 2018 16:20 WIB Polda Jabar menghentikan kasus dugaan penodaan Pancasila habieb Rizieq Syihab tersebut karena dinyatakan tidak cukup bukti. (Perjalanan Kasus Penodaan Pancasila Habib Rizieq hingga dihentikan di detik news)

2. Berita lainya mengangkat kasus penganiayaan yang dilakukan oleh Habib Bahar, beliau diduga menganiaya sopir taksi online saat istrinya pulang tengah malam pada 4 September 2018, kasus ini berjalan sejak 2018 dan beliau baru ditetapkan sebagai 
tersangka pada tahun 2020, hal tersebut diberitakan dibeberapa media massa antaranya di Suarajakarta.id pada kamis 29 oktober 2020 07:24 WIB.

3. Kasus lainnya yang juga tertuju kepada salah satu penda'I kondang yaitu kasus Ustaz Bachtiar Nasir yang disebut sebagai tersangka Penggelapan dana Yayasan Aksi 212. Berita tersebut dimuat di media online Liputan 6 pada 7 Mei 2019. Dalam berita tersebut beliau dinyatakan sebagi tersangka kasus dugaan penggelapan uang milik Yayasan Keadilan Untuk Semua (YKUS) yang dananya digunakan untuk aksi 411 dan 212.

Para Ulama adalah pewaris para Nabi, mereka adalah para penerus dakwah Rasul dan yang menghidupkan kembali sunah rasul yang telah mati. Keberadaan Ulama merupakan suatu hal yang sangat penting hampir di seluruh masyarakat muslim, begitu juga di Meulaboh. Namun sikap yang benar dalam menyikapi para ulama adalah sikap pertengahan, artinya tidak terlalu berlebihan dalam mengagungkan mereka sehingga dianggap tidak akan pernah melakukan kesalahan atau bersikap melecehkan.

Namun dewasa ini kita dihadapkan dengan sebagian media yang menyajikan berita yang berbau ujaran kebencian yang tertuju kepada beberapa Ulama di Indonesia. Sejauh mana hal tersebut berpengaruh kepada masyarakat kita khususnya di Meulaboh yang dikenal sebagai Kota Tauhid Sufi di Provinsi Aceh, satu-satunya provinsi yang menerapkan Syari'at Islam di Indonesia. Tujuan penelitian ini untuk membahas tentang bagaimana opini masyarakat Meulaboh terhadap media masa yang menyajikan berita yang berisi hatespeech terhadap Ulama

\section{KAJIAN TEORITIK}

\section{Media Massa}

Media massa telah menjadi bagian penting dalam kehidupan masyarakat saat ini. Khatimah (2018: 119) menyebut media massa sebagaikomunikasi massa yang berperan sebagai komunikator dan menjadi pelopor perubahan dalam lingkunganpublik. Melalui pesanyang berupa informasi, hiburan, pendidikan maupun pesan-pesanlainnya, media massa dipercaya dapat mempengaruhi khalayak umum.

Prasetyo (2016: 161) mengemukakan tugas dan fungsi dari media itu sendiri. Fungsi media yaitu untuk memenuhi kebutuhan informasi baik melalui media cetak maupun media elektronik dan fungsinya yaitu untuk memberikan informasi seperti berita terkini, kejadiankejadian pada hari tertentu, pertemuan-pertemuan penting, dan juga memberikan informasi tentang peristiwa-peristiwa yang diduga akan terjadikepada masyarakat dengan cara yang teratur. Tugas dan fungsi tersebut yang menjadi penentu seseorang tahu atau tidak tahu akan sesuatu hal. Bisa dikatan peran media massa sangat penting dan yang selalu dinantikan tentang informasi-informasi terbaru yang tentunya diharapkan benar adanya.

Tantangan media massa saat ini selain keabsahan beritanya juga tentang era globalisasi. Seperti yang dikemukakan oleh Sucahya (2013: 7) yaitu ketika masyarakat ingin mendapatkan informasi, mereka akan mencarinya dariberbagai sumber baik cetak maupun elektronik seperti buku, koran, radio,televisi, dan bahkan lebih mudah lagi berselancar di internet. Menjadi kewajiban setiapmedia massa untuk bekerja lebih keras lagi sehinggadapat menyesuaikan diri dengankemajuan teknologi.

Berkenaan dengan perkembangan teknologi saat ini, Habibie (2018:79) menjelaskan dua kondisi yang mempengaruhi peran media massa, kebebasan media massa dan dukungan dari teknologi yaitu kondisi pertama dimanaakses informasiyang semakin mudah akandapat meningkatkan kesadaran masyarakat untuk ambil bagian dalam penyelenggaraan 
pemerintahan yang berujung pada terciptanya kondisi yang demokratis, namun di kondisi lainnya adalah kebebasan demokratis tersebut bisa saja tidak berlandaskan tanggung jawabdan pada akhirmya menimbulkan kebebasan yang malahan tidak terarah.

Dapat dilihat bahwa posisi dan peran media sangat penting dalam masyarakat. Mengingat bahwa sifat media yang begitu fleksibel, Khatimah (2018: 119) mengutarakan bahwa masyarakat harus lebih berhati-hati karena nilainegatif atas peranan media apalagi di Indonesia bisa saja terjadi baik dari media massa ataupun media sosial. Untuk itu baik dari pengelola media maupun masyarakat itu sendiri, perlu adanya perhatian untuk dapat menyaring hal-hal negatif yang mungkin saja terjadi dan tidak dapat dihindari.

\section{Hate Speech}

Hate Speech adalah istilah yang sering muncul di media massa saat ini dan dapat diterjemahkan sebagai ujaran kebencian. Jika dilihat dari segi tata bahasanya, Hate Speech terdiri dari dua noun (kata benda) dimana kata speech sebagai head (utama), dan hate sebagai modifier (penjelas). Maka, penekanan dari frase Hate Speech adalah ujaran itu sendiri yang dimana ujaran tersebut dijelaskan olehkata hate yang posisinya sebagai noun dan berarti kebencian. Namun, kata hate apabila diposisikan sebagai verb (kata kerja) maka ia berubah makna yaitu membenci. Dalam konteks ini maka hate diposisikan sebagai noun, hal serupa juga berlaku untuk kata speech (Musyaffa, 2017: 22).

Hate speech bukan lagi menjadi permasalah sosial melainkan telah menjadi permasalahan hukum saat ini. Kemutakhiran teknologi menjanjikan informasi dapat diakses dimana saja kapan saja dan tanpa batas sehingga informasi tidak saja informasi positif bisa diterima melainkan informasi negatif juga bisa diakses oleh seluruh masyarakat seperti hate speech. Beredarnya hate speech juga dipengaruhi dengan pemahaman dangkal mengenai kebebasan berkespresi. Atas dasar kebebasan berekspresi, masyarakat secara sadar maupun tidak sadar telah melanggar hak asasi orang lain yaitu dengan membuat atau menyebarkan informasi yang tidak dapat dibuktikan dan dipertanggungjawabkan. Kasus-kasus seperti ini dapat dikategorikan ke dalam pencemaran nama baik dan hasutan kebencian dan kasus seperti ini masih menjamur di media massa kita (Royani, 2018:211).

Utami dan Darmaiza (2020: 113) mengutarakan bahwa hatespeech bisa dikategorikan ke dalam beberapa tipe yaitu dalam bentuk sindiran/sarkasme, hoax, makian, distorsi, cacian, kritik negatif. Eriyanto (2011: 124) menyebut hatespeech sebagai bagian dari marjinalisasi yaitu penggambaran buruk terhadap seseorang atau sekelompok orang. Ia menambahkan marjinalisasi itu sendiri dapat dilakukan dengan beberapa cara yaitu: 1). Eufinisme atau penghalusan makna yang biasanya banyak dipakai oleh media untuk menyebut tindakan seseorang atau sekelompok orang sehingga dapat menipu terutama rakyat. 2). Disfemisme atau pengasaran bahasa yang biasanya dipakai untuk menjelekkan sesuatu. 3). Labeling atau pemakaian kata yang ofensif kepada seseorang, sekelompok orang atau kepada kegiatan. \$) Stereotipe atau disebut juga penggambaran buruk tehadap sesuatu yaitu dengan penuh prasangka, konotasi negatif, dan bersifat subjektif (Eriyanto, 2011: 125-127).

Fitnah dan perpecahan adalah dampak yang sangat berbahaya disebabkan oleh ujaran kebencian. Negara-negara di Eropa sebagai contoh yang mempunyai pengalaman buruk terhadap ujaran kebencian seperti dilakukan Nazi sehingga negara-negara tersebut membuat kebijakan yang lebih tegas untuk melarang ujaran kebencian. Sementara Amerika, meskipun setiap penduduknya bebas berpendapat, memilih untuk mentoleransi ujaran kebencian, akan tetapi, tindakan kriminal disebabkan oleh kebencian (hate crime) telah diatur dalam perundang-undangan tersendiri. Amerika bahkan memiliki presiden pemidanaan ditujukan untuk ujaran kebencian yang dianggap menjadi penyebab aksi kekerasan. Pada tahun 1966, 
PBB yang mengeluarkan International Covenant on Civil and Political Rights (ICCPR) yang melarang "Kampanye kebencian terhadap kelompok kebangsaan, ras dan agama yang bersifat dorongan (incitement) kepada tindak diskriminasi, permusuhan dan kekerasan." Hal tersebut berpengaruh pada keseimbangan masyarakat yang mengakibatkan kecurigaan satu sama lain (Asphianto, 2017:30).

Musyaffa (2017: 21) mengutarakan polemik Hate Speech muncul semenjak terbitnya Surat Edaran (SE)Kepala Kepolisian Republik Indonesia(Kapolri) Nomor SE/06/X/2015. Namun, kemunculan SE tersebut justru menimbulkan berbagai asumsi positif maupun negatif. Tidak hanya tokoh politik danmasyarakat secara umum merespon hal itu,namun masyarakat di dunia siber, utamanyayang terlibat aktif di Media Sosial jugamemberi tanggapan berbeda.Sebagaimana tertera dalam surat edaran tersebut, Nomor 2 huruf ' $f$ ' dan ' $g$ ', menyebutkan bahwa:

"Hate Speech dapat berupa tindak pidana yang diatur dalam Kitab Undang-Undang Hukum Pidana (KUHP) dan ketentuan pidana lainnya di luar KUHP, yang berbentuk antara lain: penghinaan, pencemaran nama baik, penistaan, perbuatan tidak menyenangkan, memprovokasi, menghasut,penyebaran berita bohong, dansemua tindakan di atas memilikitujuan atau bisa berdampak pada tindak diskriminasi, kekerasan, penghilangan nyawa, dan/atau konfliksosial" (Musyaffa, 2017: 26).

\section{Etika Media}

Dalam UU Informasi dan Transaksi Elektronik (ITE) No. 11 Tahun 2008 menyebutkan aturan yang berkaitan dengan hate speech pada Pasal 28 Ayat 2, setiap orang dilarang "dengan sengaja dan tanpa hak menyebarkan informasi yang ditujukan untuk menimbulkan rasa kebencian atau permusuhan individu dan/atau kelompok masyarakat tertentu berdasarkan atas suku, agama, ras, dan antargolongan (SARA)." Polemik saat ini adalah orang bebas menyebarkan informasi berasaskan kemerdekaan berekspresi.

Kemerdekaan berekspresi dianggap ciri dari negara yang menganut paham demokratis yang menjunjung tinggi hak asasi manusia. Masyarakat terkadang latah dalam mengartikan kebebasan berekspresi. Negara Republik Indonesi telah mengatur regulasi perihal kebebasan berekspresi, peraturan ini tercantum dalam UUD 1945 Amandemen ke II yaitu dalam Pasal 28 E ayat (2) yang menyatakan bahwa "Setiap orang berhak atas kebebasan meyakini kepercayaan, menyatakan pikiran dan sikap, sesuai dengan hati nuraninya". Selanjutnya dalam ayat (3) menyatakan "Setiap orang berhak atas kebebasan berserikat, berkumpul dan mengeluarkan pendapat". Selain itu UU Hal Asasi Manusia No. 39 Tahun 1999 menyebut secara lebih detil perilahaturan yang menyangkut kebebasan berekpresi tersebut, dalam Pasal 22 ayat (3) UU tersebut menyebutkan bahwa "Setiap orang bebas mempunyai, mengeluarkan dan menyebar luaskan pendapat sesuai hati nuraninya, secara lisan atau tulisan melalui media cetak maupun media cetak elektronikdengan memperhatikan nilai-nilai agama, kesusilaan, ketertiban, kepentingan umum, dan keutuhan bangsa".

Seseorang berhak berpendapat dan mengekspresikan dirinya namun mereka dilarang untuk mencederai harga diri orang lain dan tidak menghargai hak orang lain, mereka dituntut untukpatuh pada ketentuan yang berlaku. Hal tersebut sebagaimana disebutkan dalam UUD 1945 Pasal 28J ayat (2) yang berbunyi:Dalam menjalankan hak dan kebebasannya, setiap orang wajib tunduk kepada pembatasan yang ditetapkan dengan undang-undang dengan maksud semata-mata untuk menjamin pengakuan serta penghormatan atas hak dan kebebasan orang lain dan untuk memenuhi tuntutan yang adil sesuai dengan pertimbangan moral, nilainilai agama, keamanan, dan ketertiban umum dalam suatu masyarakat demokratis. 
Teori S-O-R adalah akronim dari stimulus- organism- respon. Menurut teori ini, media massa sangat memengaruhi audience. Teori S-R mendeskripsikan proses komunikasi secara sederhana, melibatkan dua unsur, yaitu media dan audience. Respon tersebut dimodifikasi oleh organisme ( 0 ) yang stimulus dan feedback audience merupakan respon sehingga dinamakan teori S-O-R (Morissan, 2010:7). Menurut teori ini, proses komunikasi berkaitan pada perubahan sikap dengan aspek " How " bukan " What " dan "Why ". Perubahan ini berdasarkan pada proses yang ada di dalam diri individu (Christopher, 2013:288). Komunikasi pada teori ini komunikasi merupakan proses aksi komunikasi dengan asumsi bahwa kata-kata verbal, isyarat non verbal, simbol-simbol tertentu dapat menjadi stimulus terhadap orang lain sehingga melahirkan respon tertentu. Dengan demikian, fokus pada teori ini terdapat pada pesan-pesan media dan reaksi audience.

\section{METODOLOGI}

Dalam penelitian ini yang menjadi subjek penelitian adalah masyarakat Kota Meulaboh dan objek penelitian adalah opini mereka terhadap hate speech di media terhadap ulama. Penelitian ini menggunakan pendekatan kualitatif, yaitu dengan melakukan pengumpulan data melalui wawancara terhadap 4 masyarakat Kota Meulaboh dan 2 Dosen KPI STAIN Meulaboh untuk melihat data objektif terkait hate speech di media terhadap ulama sehingga didapatkan informasi yang lebih mendalam. Penelitian ini memakai model Miles dan Huberman untuk menganalisis data dengan cara melakukan penyusunan data, reduksi data dan melakukan resume data sehingga didapat suatu kesimpulan.

\section{HASIL DAN PEMBAHASAN}

Berdasarkan hasil interview terhadap beberapa responden semuanya menyatakan bahwa pemberitaan di media masa sangat memberi pengaruh yang besar bagi opini masyarakat terkait dengan kasus yang diberitakan karena segala bentuk pemberitaan di zaman sekarang sudah sangat mudah diakses oleh masyarakat, khususnya smartphone yang berbasis android atau IOS yang menemani aktivitas masyarakat sejak pagi hari.

AF, salah seorang masyarakat menambahkan: "Media menjadi seperti kartu As bagi masyarakat, ada dua sisi yang saling menguntungkan seperti simbiosis mutualisme, di satu sisi media menjadi lahan bagi penyedia berita dan di sisi lain masyarakat membutuhkan media itu sebagai wadah untuk mendapat informasi. Namun yang menjadi masalah adalah tidak semua masyarakat mempunyai filter yang baik tentang suatu pemberitan karena realita msyarakat tidak semua mengenyam pendidikan yang merata sehingga terkadang memberi efek yang berbeda-beda kepada masyarakat, sebagian mereka tidak mencari tau lagi kebenaran dari suatu berita maka hal yang demikian akan berefek negative bagi masyarakat. Sebagian masyarakat lainnya mempunyai filterasi yang bagus terhadap pemberitaan dan mampu menganalisanya dengan realita yang terjadi."

Sedikit berbeda dari pendapat yang lainnya, menurut HRP dan MS sebagai dosen di jurusan KPI di STAIN Meulaboh menyatakan bahwa "Meskipun pengaruh media adalah untuk menambah informasi terbaru untuk masyarakat namun tidak terlalu berpengaruh lagi dikarenakan masyarakat kita sudah cerdas dalam menerima berita berdasarkan pengalamanpengalaman pemberitaan yang diterima selama ini, bahkan menurut mereka yang lebih berpengaruh dalam penyampaian berita adalah media social seperti twitter, facebook, whatsapp, dan lainnya, karena infomasinya lebih update dan cepat.Akan tetapi beritanya perlu di cross check kembali di media pemberitaan online terpercaya sepertidetik atau lainnya."

HRP menambahkan bahwa pemberitaaan media itu terkadang sering keliru juga dan cenderung terlihat keberpihakannya pada pihak-pihak tertentu, hal inilah yang kemudian mengurangi pengaruh kepercayaan masyarakat terhadap media tersebut. 
HJ mempunyai pandangan dimana merasa sangat perihatin melihat media sekarang terlebih pemberitaan media sampai saat ini yang berbentuk ujaran kebencian terhadap Ulama, karena media seolah dikendalikan oleh aktor di balik pemberitaan tersebut sebagai contoh pemilik media. Ketika pemilik media ingin memberitakan hal yang menyudutkan ulama maka berita yang diterbitkan mau tidak mau harus mengikuti keinginan tersebut. Sangat disayangkan yang menjadi sasarannya adalah ulama bahkan hampir semua masyarakat menerima pemberitaan seperti itu."

Akhir-akhir ini jika dilihat seakan media mengarahkan mata pisau hanya ke ulama. Ulama seolah dikerdilkan secara keseluruhan dan agama yang dianutnya juga ikut terseret. Hal ini dirasa tidak fair karena kasus seperti ini bukan hanya menjerat ulama-ulama saja yang tidak dipungkiri mereka juga manusia yang tentu mempunyai kekhilafan tapi tokoh agama lain juga sebenarnya kalau ditelusuri tidak terlepas dari berbagai macam kasus namun tidak dipublikasikan, tergantung siapa yang menyetir pemberitaan tersebut sehingga mampu meracuni pikiran masyarakat yang tidak mampu menganalisa kebenaran dari sebuah berita.

FA menambahkan: "Sampai saat ini berita-berita seperti itu diakses setiap harinya maka akan masuk ke relung-relung pemikiran masyarakat yang akhirnya dapat mempengaruhi sudut pandang mereka terhadap ulama, baik itu menjadi baik atau menjadi buruk terkait dengan apa yang diberitakan. Intensitas informasi yang disampaikan oleh media itu sebenarnya adilkah atau tidak objektifkah atau bahkan ikut mempengaruhi penilaian kita terhadap ulama yang pada akhirnya bisa menyebabkan penurunan kepercayaan kepada sosok ulama tersebut, atau bahkan bisa memicu amarah para pendukung setianya sehingga menimbulkan kericuhan dan kebencian terhadap media yang memberitakan. Kesengajaan media untuk mengulang-ulang pemberitaan tersebut pada akhirnya berpengaruh kepada para pendengar dan pandangan mereka terhadap ulama tersebut."

HM berpendapat bahwa pemberitaan media terkait ulama kini sudah tidak menarik lagi di masyarakat. Media seolah memberitakan itu-itu saja dan terlihat mendiskriminasi sepihak atau seorang tokoh tertentu, sehingga hal ini terkesan menggiring opini seseorang. Kejadian pemboikotan media tertentu itu menunjukkan masyarakat kita sekarang sudah bisa menilai. Media seharusnya berani menyajikan berita yang sebenarnya tanpa dipengaruhi oleh pihakpihak tertentu

Dalam menyikapi permasalahan hate speech terhadap ulama di media massa, masyarakat mengharapkan media pemberitaan agar dapat bersikap netral dan tidak memihak sebelah pihak. Latar belakang masyarakat kita yang berbeda-beda; ada yang langsung menelan berita yang diterima ada yang bisa menyaring dan memastikan dulu kebenaran dari sesuatu yang diberitakan, menuntut agar media dapat bersikap sportif dalam menyajikan berita, tidak melebih-lebihkan berita hanya karena ingin menjadikannya sebagai trending topic apalagi seperti media tulis yang terkadang headline-nya berbeda sekali dengan isi berita tersebut. Media pemberitaan juga dituntut terlepas dari unsur-unsur politik dan kelompok, karena berita yang disajikan bukanlah untuk menggiring dan membentuk opini tertentu dalam masyarakat sesuai dengan keinginan pihak yang berkepentingan di baliknya.

MS menambahkan bahwa dalam Ilmu Komunikasi Islam sudah dijelaskan bahwa media itu semestinya menganut nilai-nilai atau prinsip-prinsip Islaminya seperti jujur, beretika, tidak menyebarkan berita hoax, tidak menyakiti atau merugikan sebelah pihak. Tapi kenyataan berita sekarang ini terkadang headline-nya saja sudah menggiring ke arah memburukkan sepihak. Maka dirasa nilai-nilai keagamaan dan kearifan itu harus disisipkan kembali pada awak media.

Apabila melihat dari hasil penelitian menunjukkan bahwa adanya stimulus dari pesan yang ditampilkan di media hal ini dikarenakan pesan tersebut berkaitan dengan agama dan pemuka agamanya sehingga mendapat respon dari pemeluk agama tersebut. Teori S-O-R Menurut Teori S-O-R, media massa sangat memengaruhi audience. Hal ini yang mengakibatkan terjadi 
tanggapan yang membentuk persepsi masyarakat perihal pemberitaan media. Teori S-O-R berkaitan pada perubahan sikap dengan aspek " How " bukan " What " dan " Why ". Pemberitaan media tersebut berpengaruh pada kognitif, afektik dan konatif audience-nya sehingga akan terjadi perubahan baik dari sikap, emosi dan pola pikir mereka.

Media hari ini harus benar-benar kembali ke ruh mereka dan mengembalikan semangat awal kehadiran media ke masyarakat sebagai apa. Seperti yang sudah disebutkan dalam UU dan etika media, jurnalis adalah orang-orang yang berjiwa independen, tidak mendukung suatu kelompok tertentu dan tidak melihat latar belakang mereka, seperti latar belakang agama dan kepentingan apapun. Maka media harus keluar dari hal itu dan menjadi tempat yang merdeka secara hati, pendapatan, dan profesional kerja, kembali ke kode etik dan tujuan mereka sebenarnya.

\section{KESIMPULAN}

Terdapat pengaruh yang sangat besar terhadap pemberitaan di media bagi masyarakat, mayoritas masyarakat yang dengan mudah menjangkau berita hanya dengan membuka gadget, masyarakat dapat mengakses banyak berita yang terus terbaru. Pemberitaan yang disajikan memberi pengaruh yang berbeda-beda di masyarakat tergantung dari latar pendidikan dan cara mengkonsumsi berita tersebut, ada yang menelan berita tersebut mentah-mentah sebagaimana yang diberitakan dan ada pula yang mengecek kembali keabsahannya.

Terkait dengan pemberitaan media terhadap ulama yang mengandung hate speech masyarakat kita yang masih kuat menganut nilai-nilai keagamaan menganggap hal tersebut adalah tidak layak, berita yang disajikan media diharapkan bersifat netral dan tidak memihak pihak berkepentingan manapun sehingga dapat merugikan pihak lainnya serta tidak berlebihlebihan dalam menjelek-jelekan pihak tertentu. Masyarakat juga mengharapkan agar media dapat menjadi wadah bagi masyarakat untuk mendapatkan berita yang sebenarnya tanpa ada tujuan penggiringan opini oleh pihak-pihak tertentu.

\section{DAFTAR PUSTAKA}

Asphianto, Aan. (2017). Ujaran Kebencian Dalam Sudut Pandang Hukum Positif dan Islam. AlRisalah, Vol. 17, No.1, Hal. 29-43.

Christopher. (2013). Sikap Masyarakat Surabaya Dalam Menonton Video Klip Psy-Gangnam Style Di Youtube. Jurnal E-Komunikasi, Vol. 1, No. 3, Hal. 288-297.

Eriyanto. (2011). Analisis Isi: Pengantar Metodologi Untuk Penelitian Ilmu Komunikasi dan Ilmu-Ilmu Sosial Lainnya. Jakarta: Prenada Media Group.

Habibie, Dedi Kusuma. (2018). Dwi Fungsi Media Massa. Interaksi: Jurnal Ilmu Komunikasi, Vol. 7, No. 2, Hal. 79-86.

Khatimah, Husnul. (2018). Posisi dan Peran Media dalam Kehidupan Masyarakat. Tasamuh, Vol. 16, No.1, Hal. 119-136.

Morissan, dkk. (2010). Teori Komunikasi Massa. Jakarta: Ghalia Indonesia.

Musyaffa. (2017). Hate Speech: Perspektif dan Etika di Media Siber. Syi'ar, Vol. 17, No.2, Hal. 21-32.

Nurcholis, Ahmad. (2017). Merajut Damai dalam Kebhinekaan. Jakarta: Elex Media Komputindo. 
Marisa, Siti Nurkhafifah, Dkk. Opini Masyarakat Mengenai Hate Speech Pada Media Massa Terhadap Ulama (Studi Kasus Pada Masyarakat Meulaboh, Aceh Barat)

Prasetyo, Iwan Joko. (2016). Pengaruh Pemberitaan Media Massa Terhadap Kredibilitas Pemimpin Simbolik Keagamaan. Jurnal Komunikasi, Vol. 8, No. 2, Hal. 159-169.

Royani, Yayan Muhammad. (2018). Kajian Hukum Islam terhadap Ujaran Kebencian/Hate Speech dan Batasan Kebebasan Berekspresi. Jurnal Iqtisad, Vol. 5, No.2, Hal, 211237.

Sucahya, Media. (2013). Teknologi Komunikasi dan Media. Jurnal Komunikasi, Vol. 2, No.1, Hal. 6-21.

Utami, Winda Wana dan Darmaiza. (2020). Hate Speech, Agama, dan Kontestasi Politik di Indonesia. Indonesian Journal of Religion and Society, Vol. 2, No.2, Hal. 113-128.

Undang-Undang Dasar Tahun 1945

Undang-Undang Informasi dan Transaksi Elektronik (ITE) No. 11 Tahun 2008 